\title{
ИНДИКАТОРЫ
}

Объем отгруженной инновационной продукции предприятий промышленного производства

(млн руб., до 1998 г. - млрд руб.)

\begin{tabular}{|l|c|c|c|}
\hline \multirow{2}{*}{ Год } & \multicolumn{3}{|c|}{ Объем отгруженной } \\
\cline { 2 - 4 } & $\begin{array}{c}\text { внновацинной продукиии } \\
\text { щих ценах }\end{array}$ & $\begin{array}{c}\text { на рубль } \\
\text { затрат на тех- } \\
\text { вологические } \\
\text { инновации, } \\
\text { руб. }\end{array}$ \\
\hline 1995 & 39796.8 & 39796.8 & 5.5 \\
\hline 1996 & 35334.2 & 24234.7 & 3.9 \\
\hline 1997 & 54948.9 & 32742.8 & 6.1 \\
\hline 1998 & 45776.6 & 22999.8 & 3.3 \\
\hline 1999 & 84379.6 & 24576.8 & 3.5 \\
\hline 2000 & 154135.0 & 32626.7 & 3.1 \\
\hline 2001 & 181826.1 & 33037.1 & 3.0 \\
\hline 2002 & 206313.2 & 32455.5 & 2.4 \\
\hline 2003 & 312692.0 & 43148.8 & 3.0 \\
\hline 2004 & 433003.5 & 50001.0 & 3.5 \\
\hline 2005 & 545540.0 & 52628.3 & 4.3 \\
\hline
\end{tabular}

Инновационная активность предприятий промышленного производства (проценты)

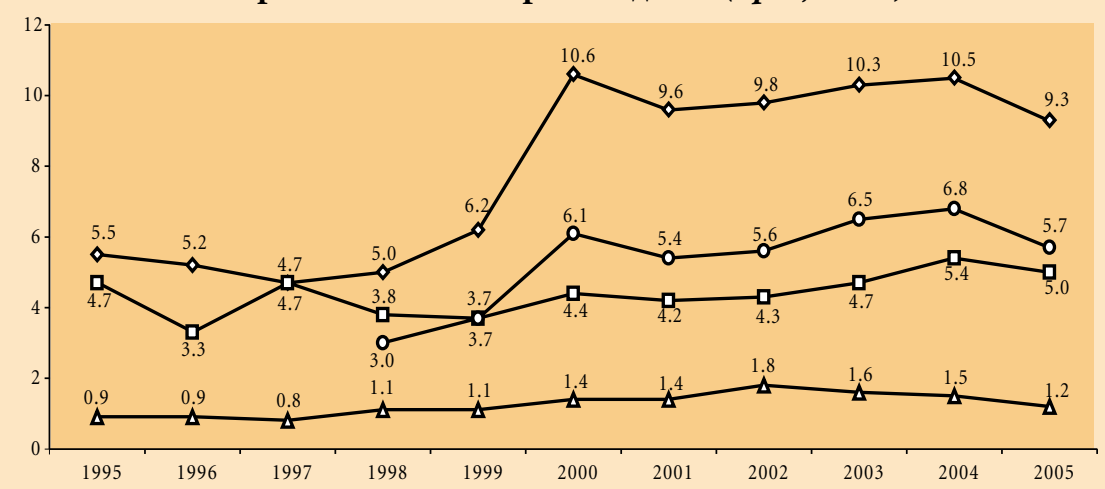

$\smile$ Удельный вес предприятий, осуществлявших технологические инновации, в общем числе предприятий промышленного производства

- - Удельный вес отгруженной инновационной продукции в общем объеме отгруженной продукции промышленного производства

$\triangle-$ Удельный вес затрат на технологические инновации в общем объеме отгруженной продукции промышленного производства

- - Удельный вес предприятий, имевших научно-исследовательские, проектно-конструкторские подразделения, в общем числе предприятий промышленного производства

\section{Международные сопоставления}

\section{Инновационная активность предприятий}

(удельный вес предприятий, осуществлявших технологические инновации, в общем числе предприятий)
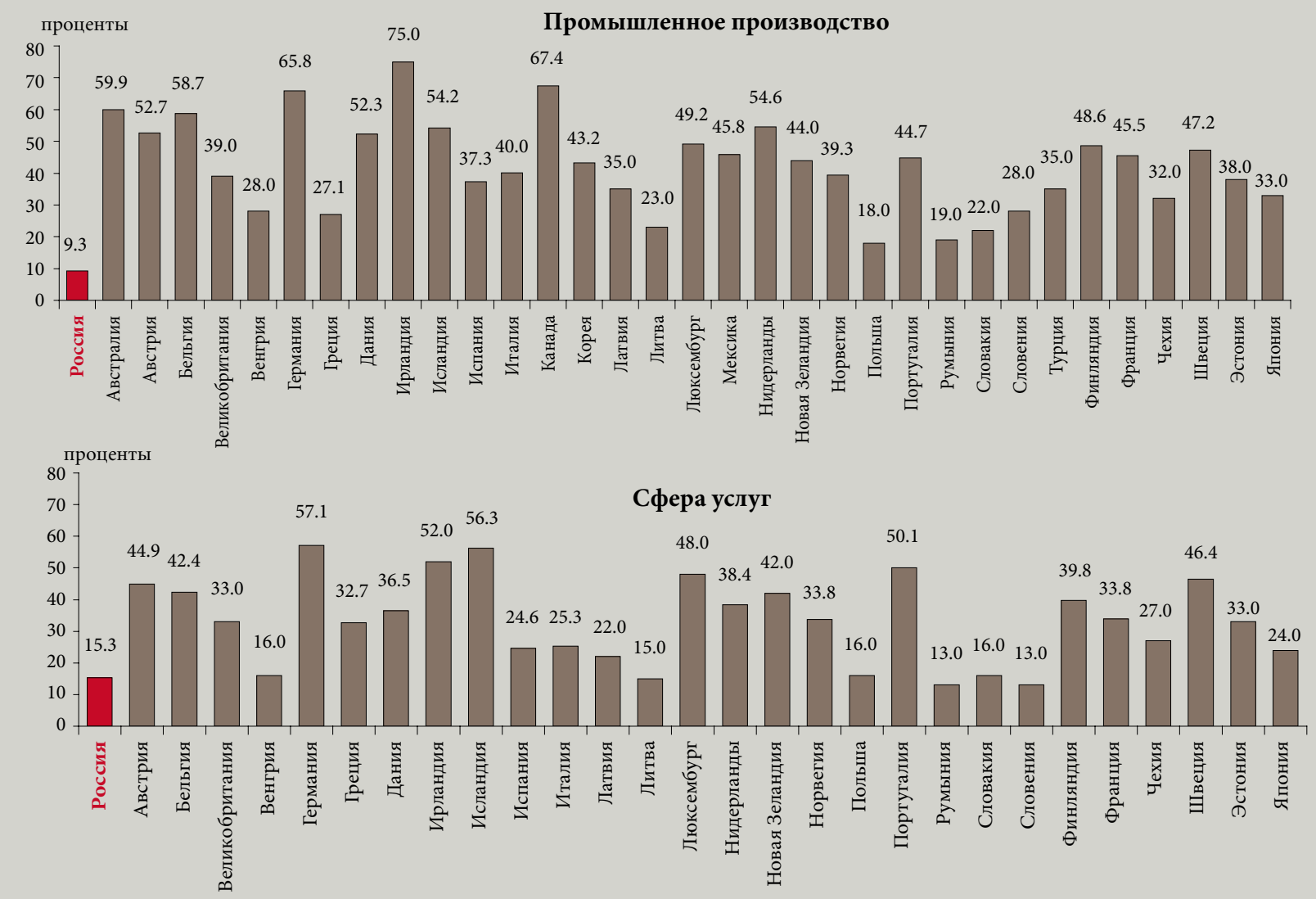

\section{Материал подготовлен Г.А. Грачевой}

Источник: Индикаторы инновационной деятельности. Статиситический сборник. М.: ГУ-ВШЭ, 2007. 